\title{
NOTE
}

\section{A SOFTWARE TO CALCULATE SOIL HYDRAULIC CONDUCTIVITY IN INTERNAL DRAINAGE EXPERIMENTS (SHC, VERSION 2.00)(1)}

\author{
Durval Dourado Neto ${ }^{(2)}$, Klaus Reichardt ${ }^{(3)}$, Adriana Lúcia da \\ Silva ${ }^{(4)}$, Osny Oliveira Santos Bacchi ${ }^{(5)}$, Luis Carlos Timm ${ }^{(6)}$, \\ Júlio César Martins Oliveira ${ }^{(7)} \&$ Donald R. Nielsen ${ }^{(8)}$
}

\begin{abstract}
SUMMARY
A software for the calculation of unsaturated soil hydraulic conductivity $K(\theta)$ is presented for commonly used methods found in the literature, based on field experiments in which a soil profile is submitted to water infiltration followed by internal drainage. The software is available at: dourado@esalq.usp.br.
\end{abstract}

Index terms: internal drainage, soil water content, water infiltration.

(1) Trabalho executado com recursos parciais do CNPq e FAPESP. Recebido para publicação em março de 2006 e aprovado em junho de 2007.

(2) Professor Titular, Departamento de Produção Vegetal, Escola Superior de Agricultura "Luiz de Queiroz" - ESALQ/USP. Caixa Postal 9, Av. Pádua Dias 11, CEP 13418-900 Piracicaba (SP). E-mail: dourado@esalq.usp.br

(3) Professor Titular, Laboratório de Física de Solos, Centro de Energia Nuclear na Agricultura-CENA/USP. Caixa Postal 96, Av. Centenário 303, CEP 13418-900 Piracicaba (SP), Brasil. E-mail: klaus@cena.usp.br

(4) Professora Magistério Secundário Técnico III, Departamento de Geomática, Colégio de Limeira - COTIL, Universidade de Campinas - UNICAMP. Caixa Postal 116, Av. Cônego Manoel Alves 129, CEP 13480-970 Limeira (SP), Brasil. E-mail: adriana.lucia.silva@gmail.com

(5) Professor Associado, Laboratório de Física de Solos, Centro de Energia Nuclear na Agricultura-CENA/USP. Caixa Postal 96, Av. Centenário 303, CEP 13418-900 Piracicaba (SP), Brasil. E-mail: osny@cena.usp.br

(6) Professor Adjunto II do Departamento de Engenharia Rural, Faculdade de Agronomia Eliseu Maciel - FAEM, Universidade Federal de Pelotas - UFPel. Caixa Postal 354, Campus Universitário s/n, Bairro Jardim América, CEP 96001-970. Pelotas (RS), Brasil. E-mail: lctimm@ufpel.edu.br

(7) Professor Titular, Escola de Engenharia de Piracicaba - EEP. Caixa Postal 226, Av. Monsenhor Martinho Salgot 560, CEP 13.414-040. Piracicaba (SP), Brasil. E-mail: jcmoliveira@merconet.com.br

(8) Full Professor, University of California, Davis, CA, 95616, USA. E-mail: drnielsen@ucdavis.edu 


\title{
RESUMO: PROGRAMA PARA CÁLCULO DA CONDUTIVIDADE HIDRÁULICA DO SOLO POR MEIO DE EXPERIMENTOS DE DRENAGEM INTERNA
}

\begin{abstract}
É apresentado neste trabalho um programa para cálculo da condutividade hidráulica do solo não saturado $K(\theta)$ para métodos da literatura mais utilizados, baseados em experimentos de campo nos quais o perfil de solo é submetido à infiltração de água, seguida da drenagem interna. O programa é disponibilizado por: dourado@esalq.usp.br
\end{abstract}

Termos de indexação: drenagem interna, conteúdo de água no solo, infiltração de água.

\section{INTRODUCTION}

The history of soil internal drainage description began with Richards, who first studied the physical processes determining water loss from field soils by drainage (Richards et al., 1956). After this, Nielsen et al. (1964), Rose et al. (1965) and Watson (1966) made pioneer contributions. This latter named the procedure for calculating hydraulic conductivity "the instantaneous profile method". Thereafter several contributions were made based on field measurements (van Bavel et al., 1968; La Rue et al., 1968; Davidson et al., 1969) and Hillel et al. (1972) published a procedure to calculate soil hydraulic conductivity functions $K(\theta)$ in situ.

Thereafter, several simple methods were published (Chong et al., 1981; Libardi et al., 1980; Sisson et al., 1980). Most of them were based on the assumption of the existence of a unit hydraulic gradient in the drainage process (Reichardt, 1993). Several others also made contributions - Jones \& Wagenet (1984) compared different methods; Bacchi (1988) improved Hillel's method with improved calculations of the derivatives; Reichardt et al. (2004) simplified equation (1) for the evaluation of $K(\theta)$ by including regression parameters in the calculation; and Hurtado et al. (2005) attributed more importance to $K(\theta)$ when the soil had drained to drier conditions.

To facilitate the establishment of $K(\theta)$ relations by the instantaneous profile method, we present a software to perform the calculations, based on field data collected in internal drainage experiments, using the methods of Hillel et al. (1972), Libardi et al. (1980), Bacchi (1988) and Reichardt et al. (2004).

\section{MATERIAL AND METHODS}

The program is fed with data of matric soil water potential $(h, \mathrm{~Pa})$ and soil water content $\left(\theta, \mathrm{m}^{3} \mathrm{~m}^{-3}\right)$ collected during a determined period $t(s)$ of soil internal drainage. To obtain these data, a soil profile is initially submitted to infiltration. When the water flux density at the soil surface becomes steady, the internal drainage process is started at a time $(t=0)$. The water supply is interrupted and the soil surface covered with a plastic sheet to avoid evaporation. For several days and perhaps weeks, if necessary, measurements of $h(z, t)$ and $\theta(z, t)$ are performed, where $z(\mathrm{~m})$ is the depth below soil surface and $t$ the drainage time. For these experimental conditions, the integration of Richards' equation leads to the expression used for the determination of the soil hydraulic conductivity $K(\theta)$ relation $\mathrm{m} \mathrm{s}^{-1}$ at any chosen depth $z=L$

$$
K(\theta)_{L}=\frac{-\int_{0}^{L}\left[\frac{\partial \theta(z, t)}{\partial t}\right] d z}{\left[\frac{\partial H(z, t)}{\partial z}\right]_{L}}
$$

where $H=(h+z)$ is the total hydraulic head $(\mathrm{Pa})$.

\section{Hillel et al. (1972) Method}

These authors used equation (1) for calculations by finite differences. At that time computation tools were not as developed as today, so $\partial \theta / \partial t$ was estimated graphically, point by point, from graphs of $\theta(z, t)$. Thereafter $(\partial \theta / \partial t) \Delta z$ would be calculated for each depth increment. The authors evaluated the numerator of equation (1) by summing these values $\Sigma(\partial \theta / \partial t) \Delta z$ to depth $L$. The gradients in the denominator of equation (1) were also calculated graphically, point by point, from graphs of $H(z, t)$. The parameters of the $K(\theta)$ relation were obtained from a semi-log plot of $K$ for each depth $L$ versus $\theta$. They proposed the relation:

$$
K(\theta)=\alpha \exp (\beta \theta)
$$

\section{Libardi et al. (1980) Method}

These authors used equation (1) assuming that i) $\mathrm{K}(\theta)$ is given by:

$$
K(\theta)=\mathrm{K}_{0} \exp \left[\beta\left(\theta-\theta_{0}\right)\right]
$$

where $K_{0}$ and $\theta_{0}$ are the values of $K$ and $\theta$ at $t=0$, respectively; that the total hydraulic gradient $\partial H / \partial z$ is unity for all times; and that the average $\theta^{*}$ in the profile $(0 \leq \mathrm{z} \leq L)$ is linearly related to the $\theta$ value at $\operatorname{depth} L$ :

$$
\theta^{*}=\alpha \theta+b
$$

Using the last assumption, 


$$
\int_{0}^{z}\left(\frac{\partial \theta}{\partial t}\right) d z=z\left(\frac{\partial \theta^{*}}{\partial t}\right) \approx a z \frac{\partial \theta}{\partial t}
$$

equation (1) is approximated by

$$
-a z \frac{\partial \theta}{\partial t}=K_{0} \exp \left[\beta\left(\theta-\theta_{0}\right)\right]
$$

Integrating equation (6) from $\left(t=0, \theta=\theta_{0}\right)$ to $(t=t, \theta=\theta)$ results in:

$$
\left(\theta_{0}-\theta\right)=\frac{1}{\beta} \ln t+\frac{1}{\beta} \ln \left(\frac{\beta K_{0}}{a}\right)
$$

The constant $a$ is obtained from a regression of measured values of $\theta^{*}$ versus measured values of $\theta$. When $\theta_{0}$ is measured directly in the field, the parameters $K_{0}$ and $\beta$ are obtained from a regression of $\left(\theta_{0}-\theta\right)$ versus $\ln t$ (equation 7$)$.

\section{Bacchi (1988) Method}

This author improved the calculation of the derivatives proposed by Hillel et al. (1972). For $\partial \theta / \partial t$ he simply took the derivative of the regression equation of $\theta$ versus $\ln t$. And because $H$ is generally linearly related to $z$, he obtained $\partial H / \partial z$ from the slope of the linear regression equation between $H$ and $z$. He was aware that $\partial H / \partial z$ had the same value for all depths and varied only in time. He suggested $K(\theta)$ relations described by equations (2) and (3).

\section{Reichardt et al. (2004) Method}

These authors parameterized equation (1) by fitting measured values of $\theta(z, t)$ and $h(z, t)$ data for each chosen depth $z=L$ to the following logarithmic models:

$$
\begin{aligned}
& \theta_{\mathrm{L}}(t)=a+b \ln t \\
& S_{\mathrm{L}}(t)=c+d \ln t \\
& H_{\mathrm{Z}}(t)=e+f \ln t
\end{aligned}
$$

where $S_{L}(\mathrm{~cm})$ is the soil water storage for the layer $0 \leq z \leq L$. When the fitting of the experimental data to equations (8), (9) and (10) is significant, equation (1) can be parameterized as follows:

$$
K(\theta)_{L}=\left\{\frac{-d \exp \frac{1}{b}\left(a-\theta_{0}\right) \cdot \exp \left[-\frac{1}{b}\left(\theta-\theta_{0}\right)\right]}{e^{\prime}+\frac{f^{\prime}}{b}(\theta-a)}\right\}
$$

where $e^{\prime}=\left(e_{1}-e_{2}\right) / \Delta z, f=\left(f_{1}-f_{2}\right) / 2 \Delta z$ and $e_{1}, e_{2}, f_{1}$ and $f_{2}$ are the coefficients of equation (10) for the regressions of $H(t)$ at the depths $(L+\Delta z)$ and
$(L-\Delta z)$. Equation (11) has the form of equation (3) where $K_{0}$ is a function of $\theta$, when $\partial H / \partial z$ differs from unity. Equations (3) and (11) are identical only when $e^{\prime}=1, f^{\prime}=0$, which corresponds to the unit hydraulic gradient.

\section{The program}

The software consists of five files, one for the input of user data and one for the calculation of $K(\theta)$ by each of the four described methods. Firstly, the user introduces his data, collected as described in the first paragraph of this item, into file 1 . The table of file 1 contains a template, of data presented in Cadima (1978), for a Haplustox (Latossolo Vermelho-Amarelo, fase arenosa) of Piracicaba, SP, Brazil. The soil water matric potential $h$ and soil water content $\theta$ were measured for $t=0$ to $t=45$ days, at depths of $z=0.15$; $0.30 ; 0.45 ; 0.60 ; 0.75 ; 0.90 ; 1.05 ; 1.20$; and $1.35 \mathrm{~m}$. The software output for these data consists of the parameters of equations (2) and (3): $\alpha, \beta, K_{0}$ and $\theta_{0}$ by the methods of Hillel et al. (1972), Libardi et al. (1980) and Bacchi (1998), and of the parameters of equation (11): $a, b, d, e^{\prime}, f^{\prime}$ and $\theta_{0}$, by the method of Reichardt et al. (2004). The user simply substitutes the data of the input table by his own, and the program calculates the new $K(\theta)$ relations.

\section{LITERATURE CITED}

BACCHI, O.O.S. Comparative analysis of soil hydraulic conductivity methods for unsaturated soils. Piracicaba, Escola Superior de Agricultua "Luiz de Queiroz", 1988. 94p. (Tese de Doutorado)

CADIMA, Z.A. Physico-hydraulic characterization of a Yellow Red Latosol, sandy phase (Haplustox). Piracicaba, Escola Superior de Agricultura Luiz de Queiroz, 1978. (Tese de Doutorado)

CHONG, S.K.; GREEN, R.E. \& AHUJA, L.R. Simple in situ determination of hydraulic conductivity by power function descriptions of drainage. Water Res. Res., 17:1109-1114, 1981.

DAVIDSON, J.M.; STONE, L.R.; NIELSEN, D.R. \& LARUE, M.E. Field measurement and use of soil-water properties. Water Res. Res., 5:1312-1321, 1969.

HILLEL, D.; KRENTOS, V.D. \& STYLIANOU, Y. Procedure and test of an internal drainage method for measuring soil hydraulic conductivity in situ. Soil Sci., 114:395-400, 1972.

HURTADO, A.L.B.; CICHOTA, R. \& JONG VAN LIER, Q. Parametrização do método do perfil instantâneo para a determinação da condutividade hidráulica do solo em experimentos com evaporação. R. Bras. Ci. Solo, 29:301307, 2005.

JONES, A.J. \& WAGENET, R.J. In situ estimation of hydraulic conductivity using simplified methods. Water Res. Res., 20:1620-1626, 1984. 
LA RUE, M.E.; NIELSEN, D.R. \& HAGAN, R.M. Soil water flux below a ryegrass root zone. Agron. J., 60:625-629, 1968.

LIBARDI, P.L.; REICHARDT, K.; NIELSEN, D.R. \& BIGGAR, J.W. Simple field methods for estimating soil hydraulic conductivity. Soil Sci. Soc. Am. J., 44:3-7, 1980.

NIELSEN, D.R.; DAVIDSON, J.M.; BIGGAR, J.W. \& MILLER, R.J. Water movement through Panoche clay loam soil. Hilgardia, 35:491-506, 1964.

REICHARDT, K. Unit gradient in internal drainage experiments for the determination of soil hydraulic conductivity. Sci. Agric., 50:151-153, 1993.

REICHARDT, K.; TIMM, L.C.; BACCHI, O.O.S.; OLIVEIRA, J.C.M. \& DOURADO-NETO, D. A parameterized equation to estimate soil hydraulic conductivity in the field. Aust. J. Soil Res., 42:283-287, 2004.
RICHARDS, L.A.; GARDNER, W.R. \& OGATA, G. Physical processes determining water loss from soil. Soil Sci. Soc. Am. Proc., 20:310-314, 1956.

ROSE, C.W.; STERN, W.R. \& DRUMMOND, J.E. Determination of hydraulic conductivity as a function of depth and water content for soil in situ. Aust. J. Soil Res., 3:1-9, 1965.

SISSON, J.B.; FERGUSON, A.H. \& van GENUCHTEN, M. TH. Simple method for predicting drainage from field plots. Soil Sci. Soc. Am. J., 44:1147-1152, 1980.

van BAVEL, C.H.M.; STIRK, G.B. \& BRUST, K.J. Hydraulic properties of a clay loam soil and the field measurement of water uptake by roots: Interpretation of water content and pressure profiles. Soil Sci. Soc. Am. Proc., 32:310317,1968 .

WATSON, K.K. An instantaneous profile method for determining the hydraulic conductivity of unsaturated porous materials. Water Res. Res., 2:709-715, 1966. 